\title{
Political Economy of Violence: Interpreting the Nigerian Boko Haram
}

\author{
Alafuro Epelle (Ph.D) \\ Department of Political Science, Ignatius Ajuru University of Education, Rumuolumeni, Port Harcourt \\ alafuroepelle@yahoo.com
}

Iwarimie B. Uranta

Department of Political Science, Ignatius Ajuru University of Education, Rumuolumeni, Port Harcourt

Doi:10.5901/mjss.2014.v5n10p528

iwarimie@yahoo.com

\section{Abstract}

This paper characterizes the extant Boko Haram phenomenon as a reflection of the very dependent and weak character of the Nigerian State. Employing the Marxian political economy approach it draws a sharp signal from the manner in which the state's indifference to the contradictions of social materialism is generating constant centrifugal forces against its autonomy. It anchors on a very basic fundamental hypothesis, that Boko Haram is symptomatic of not only a weak state, but also a desperate and marginalized class whose only source of drawing the state's attention is through organized violence. We argue further that, what is described as Boko Haram in an empirical form is merely a coincidence between serious private accumulation of the state's GDP and lack of Focused Civil Empowerment (FCE). Consequently, the study recommends, inter-alia, the accommodation of the lumpen -proletarian Boko Haram membership in the state economic planning machinery together with a decentralization or restructuring of the Economic and Financial Crimes Commission (EFCC) to critically monitor the appropriation of Local Government councils' allocations to ensure a domestication of human capacity development at the rural level, thus making Boko Haram members less susceptible to violence and more sympathetic to peace.

Keywords: State, Boko Haram, Political Economy, violence, development.

\section{Introduction}

In contemporary Nigeria it is commonplace for scholars to draw from the dependent character of the State to explain away the manner in which the civil society is becoming highly restive and confrontational to the former expressing their discontent and disenchantment with the ugly state of things in the country by carrying arms and explosives and destroying lives and properties.

We argue in this work that this ugly scenario can significantly be located within the capitalist mode of social reproduction in which many who are dissatisfied struggle with their existential condition individually and/or collectively, under all kinds of identities such as class, ethnic or clan groups, religious groups and ideologies to change, or at least improve their position (Ogban-lyam, 2005:22). The basic contention of this work therefore is that, although some other factors as religion and ethnicity may contribute in underpinning the violence, the nature and character of the Nigerian state is a major factor in the emergence of the deepening politico-religious violence in the northern part of the country described popularly as Boko Haram.

To ensure an orderly presentation, six major sections follow this introduction; they are: conceptual clarification; theoretical framework, politics of Boko Haram; its political economy dimensions; implications for national security and development; the conclusion and recommendations form the final part of the paper.

\section{Conceptual Clarification}

\subsection{Violence}

This is a physical form of conflict intended to hurt or kill somebody. Conflict can exist between or among individuals, ethnic or other social groups without resort to physical force; but when physical force is applied, it becomes violent. Although this conceptual clarification needs to be properly made especially for intellectual purpose, the two concepts (conflict and violence) would be interchangeably used in this paper.

Ogban-Iyam (2005:4), made a relevant input from which we can draw a summary. To him: 
Conflicts assume violent character when physical force is exerted for purposes of violating, damaging or abusing. Most conflicts and violence are social in character as human beings pursue their survival and security needs with other human beings particularly when these needs are not or cannot be met simultaneously for all concerned.

The state in performing its historical role often employs violence to contain the constant reactions of the marginalized and alienated class.

\subsection{Boko Haram}

This is often seen as a Nigerian islamic group which seeks the imposition of Sharia law in the Northern states of the country. Having presently an undefined structure and chain of command, the official Arabic name of the group is Jama'ata Ahlis Sunna Lidda Awatiwal Jihad, which in English means "people committed to the propagation of the prophet's teaching and Jihad". It became known internationally following sectarian violence in Nigeria in 2009, but residents of Maiduguri where it was formed in 2002 dubbed it "Boko Haram". Loosely translated from the local Hausa language it means "western education is forbidden". Residents, it was said, gave it the name because of its strong opposition to western education-which it sees as corrupting the Muslims. Boko Haram, derived from Hausa word "Boko" means "animist" and the Arabic word "Haram" means sin or forbidden (see Google search Wikipedia, The Free Encyclopedia 2011).

Ideologically, Boko Haram equally opposes not only western education but western culture and modern science. Consequently, the group forbids the wearing of shirts and pants and the act of voting in elections.

Sani (2011) has described Boko Haram as an Islamic sect which broke out from the Islamic Almajiri school (which forbids western education) found largely in the northwestern part of Nigeria. The Boko Haram group began as Sahaba group in 1995. The main leader of the group then was one Abubakar Lawan who later left for the University of Medina to study; when he left, the older clerics conceded the leadership to Mallam Muhammed Yusuf, who was young and versatile. But immediately Yusuf took over, the doctrine of the sect changed; he abandoned the older clerics and came up with Boko Haram. On international links, available information indicates that the group emanated from an orthodox teaching slightly resembling that of the Taliban in Afghanistan and Pakistan.

Adele (2011:58) has indicated that the sect is being allegedly sponsored by some northern politicians, having about 1.5 million followers and believes that banking, taxation and jurisprudence in the country are completely infidel. They also believe that western education was unislamic as it propagates the opposite of what Allah and his prophet, Mohammed, had ordained.

\section{Theoretical Framework}

This work is anchored on the hypothesis that those who sponsor and/or are sponsored to participate in Boko Haram activities do so for ultimate material reason. Based on this premise, we have decided to employ the Marxian Political Economy approach as a framework for analysis. This method is materialistic and demands that relations of production be studied in the process of their emergence, development, demise and their replacement by other relations of production. The theory further enables us to take account of the systematic interactions of the different superstructural elements of society, especially the political, social, and belief systems and their implications for the objective character of the economy (Okodudu, 2010:206). This, as Marx himself asserts, is because the mode of production of material life conditions the social, political and intellectual life process in general (Lenin: 1978). Ake (1981) clarifies this further. According to him, the material condition of man is what determines the nature of the political system (Ake, 1981:1-2). In his words:

Once we understand what the material assets and constraints of a society are, how the society produces goods to meet its material needs, how the goods are distributed, and what types of social relations arise from the organization of production, we have come a long way to understanding the culture of that society, its laws, its religious system, its political system and even its modes of thought. (Ake, 1981:1-2)

In essence, the political economy approach investigates the materialistic aspect of dialectics, its resultant conflicts and crisis and its effect on the socio-political lives of members of a society. It is a method which gives primacy to material conditions (particularly economic factors) in the explanation of social life. It portrays the dynamic character of reality; gives insight to the dynamics of the social world; profers a comprehensive view of society while treating problems concretely rather than abstractly (Ake, 1981:5-7). Ekekwe (2009:17) adds further:

... if we want to understand social activity and society from the point of view of political economy, we must first of all "atomize" them into their different elements. In other words, we must first breakdown society into its smallest units which, obviously, are the individual human beings ... To live he must produce the means to life. It is for purposes of 
individual and social maintenance and reproduction that productive activity assumes the very high degree of importance assigned to it. When these basic sources of material maintenance are lacking man, especially within the marginalized class, is bound to adopt a confrontation method (class struggle) to survive.

Conflict resolution scholars argue that conflict has an ontological basis in human needs and that it is the denial of these needs that makes resolvable differences to degenerate into armed violence or armed conflict.

Within this context it is expressly easy to understand the nature and character of the violence currently being experienced and described in the Northern part of Nigeria as Boko Haram.

\section{The Politics of Boko Haram}

Okei-Odumakin (2011:51) is of the opinion that "Government has been slow and indecisive on the issue of Boko Haram". This view is corroborated by Archbishop Alaba Job, President Catholic Bishops' conference of Nigeria, who said at a recent conference in Abakaliki, Ebonyi state, that the blame" ... is with the government, because the State Security Service (SSS) in the past five years has been monitoring these people. If you go to Borno you will discover that their headquarters is at Central Railway quarters in Maiduguri". Little wonder Okei-Odumakin decries a situation whereby security agencies parade "some haggard looking persons" as Boko Haram suspects and then allow the case to fade off. In her opinion, this tenuous approach emboldens the militants to regroup and strike again, thus causing crisis.

Okei-Odumakin (2011:51) further indicated that some fundamentalists who were arrested for alleged nefarious activities under the administration of Obasanjo in 2007 were later released by his successor, late President Umaru Yar'Adua. That decision was allegedly taken on the assumption that the suspects were actually victims of religious persecution. Ironically one of them, Muhammad Yusuf, returned to the society to nurture the now dreaded Boko Haram sect, thus creating crisis for the Yar'Adua administration. In an attempt to clip the wings of the group, the late Yar'Adua, decided to use the military option to suppress the insurgency.

The military arrested Yusuf, but he was allegedly killed after the military task force handed him over to the police. It is also alleged that some leaders give the insurgents support, by getting them out of detention so they would not have to answer for any wrong doing. That is why some people believe that Boko Haram insurgence is more political than religious (Adeyemo 2011). Archbishop Job puts it this way: "Boko Haram is not totally religious. It is political and those behind them should be bold enough to talk to us, so that we can tell them where they belong". Insinuations within political circles is that some of those who are opposed to Goodluck Jonathan becoming Nigeria's president are working to ensure that the man does not have enough comfort in office to be able to think of asking for a second term in 2015 or even to execute people-oriented developmental projects during his current first tenure. Apologists of this position cite the recent post presidential elections riots in April 2011 that led to the murder, in cold blood, of many National Youth Service Corps (NYSC) members and hundreds of other Nigerians in Bauchi, Niger, Borno and Kaduna States by youths protesting the victory of President Goodluck Jonathan on April 26, 2011. Many still believe that the out-come of this election is the main cause of the prevailing undeclared war and restlessness in some parts of the North (Tell Oct. 17, 2011:52). Joseph Waku, the vice chairman of Arewa Consultative Forum, corroborating this said: "Boko Haram is political. It goes back to what we are saying. Do what the people want" (Tell Nov. 21, 2012:46). An anonymous retired Commodore in the Nigerian Navy was quoted by Tell magazine (2012:43) as saying: "a few wealthy ones are the people giving support to the insurgents because terrorism requires a lot of funding". To him, the elites are supporting them financially with the objective of using them to destabilize the existing state apparatus.

The State's lackadaisical attitude to this group can be variously explained. Firstly, at the time the group began to take root in Nigeria up to 2009, the state has been under the leadership of an Islamic faithful (late president Yar'Adua), who probably due to the emotional nature of religion refused to tackle the insurgents firmly and decisively. Corroborating this view Alabi (2007:94) noted that:

In Nigeria, religion has provided a sense of cleavages, classes .... ethnicities and demand for social and economic advantages of members. Members of a particular religion seem to be more accommodating to their members than to other groups and, in fact, these religions are in contest for the advantages of their members. In this regard, whenever a member of their faith occupies a position of influence it is usually seen as an opportunity to advance both individual and corporate interest.

Besides, most of those in the armed forces are also not immuned to this religious and emotive sentiments which probably has increased their passion and dampened their zeal in the discharge of their official responsibilities. Media reports during religious crisis in the northern part of the country sometimes mention cases where non-Muslim civilians were killed by members of the armed forces while attempting to contain the crisis, thus worsening the situation (Alabi, 2007).

The politics of this phenomenon is further corroborated by the fact that in spite of the arrest and killings by the Joint 
Task Force (JTF), leaders and members of the group are still waxing stronger. Their reinforcement is not only made rapid by the withdrawal of many northern university students from study between 2004 to 2009 to pay allegiance to Yusuf, members also had to pay a daily levy of 100 naira to their leader. This provided the basic source of funding for the sect in addition to surreptitious donations and sponsorship from politicians, government officials and other individuals or organizations within the country.

It is equally regrettable to note that lack of relative autonomy by the Nigerian state has indeed led to its inability to successfully prosecute and convict top northern politicians implicated in the Boko Haram saga. The nature and character of the post-colonal state in Nigeria has led many scholars to associate the state with rent seeking, patrimonialism and prebendalism, thus resulting in its lack of relative autonomy, leading consequently to its inability to successfully prosecute and convict top northern politicians implicated in the Boko Haram saga. For example Ali Modu Sheriff and Senator Ali Ndume who have been variously fingered as patrons of the sect are yet to be convicted for any felonious offence (Jega 2002:36, Adeyemo 2011:27).

Mudashiru (2011:14) submits that the only sensible interpretation of this ideology and philosophy is that advocates of Boko Haram believe that the elites have been able to suppress and oppress them due to their (latter's) exposure to western education. Therefore, wiping out western education within their domain is the only path to freedom for their people, hence the various activities of the sect.

\section{Chronicle of Boko-Haram Attacks}

\begin{tabular}{|c|c|c|c|c|c|}
\hline $\mathbf{S} / \mathbf{N}$ & Date & Nature & No. of Deaths & Venue & State Reaction \\
\hline 1. & $26 / 7 / 2009$ & All night attack on Dutsen-Tanshi Police & 39 & Bauchi & \\
\hline 2. & 27/7/2009 & $\begin{array}{l}\text { Invasion of Potiskum Divisional Headquarters, Yobe } \\
\text { State. }\end{array}$ & 4 & Yobe state & \\
\hline 3. & $29 / 7 / 2009$ & Confrontation with security men at mamudo village & 33 & Yobe state & \\
\hline 4. & $29 / 7 / 2009$ & All night battle with security men at Railway terminals & Scores & Maiduguri, Borno state & \\
\hline 5. & $07 / 7 / 2010$ & Jail break, set ablaze Bauchi centre prison & - & Bauchi & $\begin{array}{l}92 \text { Boko Haram } \\
\text { members arrested }\end{array}$ \\
\hline 6. & 08/09/2010 & Set ablaze Bauchi central prison & - & Bauchi & \\
\hline 7. & $01 / 10 / 2010$ & Explosion near the eagle square & 12 & Eagle square Abuja & \\
\hline 8. & Jan 2010 & Bomb strike & 4 & Dala-Alemderi Maiduguri & \\
\hline 9. & 2010 & Religious rioting; death of Christians & 992 & Jos & - \\
\hline 10. & Dec. 31,2010 & Mogadishu Mammy, Market Bombing & & Abuja & \\
\hline 11. & Jan. 28, 2011 & $\begin{array}{l}\text { Borno State ANPP Gubernatorial Candidate killed with } 4 \\
\text { police officers and 12yr. old boy }\end{array}$ & 7 (6) & Maiduguri & \\
\hline 12. & Feb. 9, 2011 & $\begin{array}{l}\text { Grave condition for peace given: resignation of Governor } \\
\text { A Sheriff }\end{array}$ & /l & Borno State & \\
\hline 13. & May 9, 2011 & Rejected Amnesty offer, attack on two Islamic scholars & 2 & Borno & Offer of Amnesty \\
\hline 14. & $02 / 03 / 2011$ & Attack on DPO's residence, Rigasa Area & 2 & Kaduna & \\
\hline 15. & 29/03/2011 & - Plot of bomb attack & - & Maiduguri & $\begin{array}{l}\text { Police treated a bomb } \\
\text { plot in ANPP election } \\
\text { rally }\end{array}$ \\
\hline 16. & April 1, 2011 & Attack on police station injuring 2 policemen & - & Dutsen Tanshi, Bauchi state & - \\
\hline 17. & April 9, 2011 & Bombing of police station & - & Maiduguri & - \\
\hline 18. & April 102011 & Bombing of INEC office & 7 & Maiduguri & - \\
\hline 19. & April 20, 2011 & Killed a Muslim cleric & 1 & Maiduguri & - \\
\hline 20. & April 22, 2011 & Jail break, freed 14 prisoners & - & Yola, Adamawa State & - \\
\hline 21. & April 2011 & Killing of NYSC members & - & $\begin{array}{l}\text { Bauchi Niger Borno, Kaduna } \\
\text { states }\end{array}$ & $\begin{array}{l}\text { Seen as post election } \\
\text { violence }\end{array}$ \\
\hline 22. & May 29,2011 & Series of bombings & 15 & \begin{tabular}{|c|} 
Bauchi \\
\end{tabular} & - \\
\hline 23. & June 17,2011 & $\begin{array}{l}\text { Bombing of police headquarters targeting police IG. Gen. } \\
\text { Hafiz. Ringim }\end{array}$ & 2 & Abuja & Conducted investigation \\
\hline 24. & June 26,2011 & Attack on Beer garden & 25 & Maiduguri & - \\
\hline 25. & June 27,2011 & Bombings & 5 & Maiduguri & - \\
\hline 26. & July 03, 2011 & Attack on beer garden & 20 & Maiduguri & - \\
\hline 27. & July 1, 2011 & Bombing at All Christian Fellowship centre & - & Suleja Niger State & - \\
\hline 28. & July 11,2011 & UNIMAID closed down for fear & - & Maiduguri & - \\
\hline 29. & Aug. 12, 2011 & The prominent Muslim cleric, Liman Bana, Shot dead & 1 & North & Conducted investigation \\
\hline 30. & Aug. 26, 2011 & UN headquarters blown up by suicide car bomber. & $\begin{array}{l}21 \text { dead, Dozens } \\
\text { wounded }\end{array}$ & Abuja & Conducted investigation \\
\hline 31. & Oct. 16, 2011 & & 1 & Maiduguri & Conducted investigation \\
\hline 32. & Nov. 4, 2011 & Attack on police station, churches and banks & $100-150$ & Damaturu & \\
\hline
\end{tabular}




\begin{tabular}{|c|c|l|c|c|c|}
\hline 33. & $\begin{array}{c}\text { Dec. } 22-23, \\
2011\end{array}$ & Boko Haram clash with security forces & $68+$ & Maiduguri/Damaturu & - \\
\hline 34. & Dec. 25, 2011 & Bombing of Catholic church during Christmas mass & 45 & Madalla & - \\
\hline 35. & Jan. 5- 6, 2012 & Attack on churches and businesses & 185 & Kano & - \\
\hline 36. & April 8, 2012 & Bombing of a church on Easter Sunday & 38 & Kaduna & - \\
\hline 37. & June 17,2012 & Bombing of three churches & $12-19$ & $\begin{array}{c}\text { Kaduna/Wusasa, Sabon } \\
\text { Gari }\end{array}$ & - \\
\hline 38. & July 8, 2012 & Killing of politicians and 50 others & 52 & Matse Village, Jos & - \\
\hline 39. & July, 7, 2012 & Dozens of people die in village attack & 37 & Barkin Ladi \& Riyom, Jos & - \\
\hline 40. & Sept. 23, 2012 & Attack on a church & 2 & Bauchi & - \\
\hline 41. & $06 / 07 / 2013$ & Attack on GSS Mamado, Potiskum & 40 & Yobe & \\
\hline 42. & $18 / 08 / 2013$ & Attack on Konduga community & 50 & Maiduguri & \\
\hline
\end{tabular}

Sources: Sani (2011:39-41); Tell (2012:44-45) etc

\section{Political Economy of Boko Haram}

The fundamental argument of this paper is that the material condition of Boko Haram adherents is the basis of the violent conflict. The Marxian Political Economy theory states that every social problem has a history and that they derive essentially from man's instinct to subsist and reproduce himself. Taking it further, our pattern of politics since the era of flag independence in October 1960 has remained essentially unchanged: intense contestation for power, brute force, electoral robbery, and winner-takes-it-all victory. In this bizarre struggle for political power, according to Ake (1981:10), our leaders employ every available means to get into elective positions.

The elitist Boko Haram whom the president admits exists in his cabinet can be categorized into this. Those who have no means of getting into political office are sponsored to make the political space unstable, while those who are occupying political office do their bit to destabilize other leaders in order to up-stage them and take over their coveted positions.

Dasuki (2012:23) on his part described Boko Haram as a product of lack of socio-economic justice. According to him:

...what I am saying is that if government does justice at all levels, if government addresses the problem of the people there would be less social unrest in the society. But instead what do we see everyday? Corruption with impunity.

He went further to opine that "if our leaders are close to the people and are willing to listen, even this problem of Boko Haram would not have arisen".

In other words, most of those involved directly in these attacks are materially motivated as they are sustained economically by their elitist leaders who themselves are also not divorced from ultimate prebendal goals.

The following triangular and equational descriptions will further drive home our argument.

Fig. A

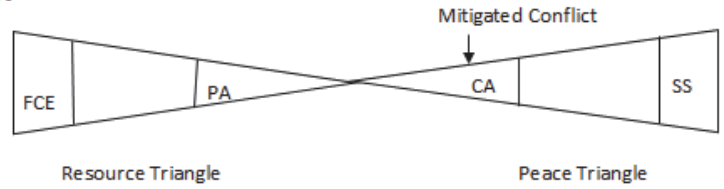

Fig. B

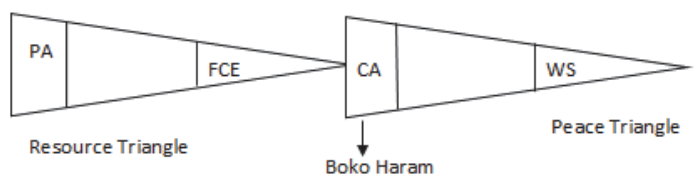

Source: Developed by the Authors

Figure $A$ above shows that a widened Focused Civil Empowerment (FCE) and compressed private accumulation (PA) in a resource triangle is most likely to produce minimal civil armament (CA) and a strong state (SS) leading to a robust peace triangle, while conversely;

Figure $B$ shows that a cavalier private accumulation (PA) and a minimal Focused Community Empowerment (FCE) will produce maximum civil armament (CA) and a weak state (WS) with its negative implication for peace and tranquility in the society. 
Furthermore;

$\mathrm{RA}-\mathrm{PA}-\mathrm{FCE}=$ Peace

$\mathrm{RA}+\mathrm{FCE}-\mathrm{PA}=$ Peace + Peace Culture

$\mathrm{RA}+\mathrm{FCE}+\mathrm{PA}=\mathrm{CA}$

$\mathrm{RA}+\mathrm{PA}-\mathrm{FCE}=\mathrm{CA}+$ Boko Haram

Where;

$\mathrm{RA}=$ revenue allocation

$F C E=$ focused civil empowerment

$\mathrm{PA}=$ private accumulation

$\mathrm{CA}=$ civil armament

$\mathrm{SS}=$ strong state

WS = weak state

The above scenario is further confirmed by Jega (2002) who argue that about $67 \%$ of Nigerians are decisively entrapped in conditions of acute poverty. Various factors have inflicted this poverty syndrome on the Nigerian masses. This include unemployment, inflation and corruption especially at the local government councils. The 774 local governments in Nigeria receive allocations from the Consolidated Revenue Fund. They equally constitute the end point of the national and state governments' economic programmes, but many of the local councils lack an institutionalized economic framework for managing children and youths especially at their formative stages in life through viable social and economic policies.

This creates mass poverty, frustration and aggression on the long run and serves to condition their minds and attitudes to susceptibility towards elite and other religious manipulation motivation and mobilization to partake in riots and reprisal attacks. We argue further that it is within this context that we can locate the character, organization and development of ethno religious phenomenon like, Boko Haram. This research even traced this morbid poverty situation back to 2005, providing a porous economic background for the north.

For instance, the living standard survey conducted by the National Bureau of Statistics (NBS) for the year 2010 shows that poverty has been on the increase while standard of living has continued to fall. In a report released last February, the agency found that absolute poverty in the country increased from 54.4 percent in 2004 to $60.9 \%$ in 2010 (that is 99milion Nigerians). The report further noted that Northwest and North-east Zones of the country recorded the highest poverty rates with $70 \%$ and $69 \%$ respectively in 2010 while the south-west recorded the least at $49.8 \%$. By Nigerian Bureau of Statistics' estimation, $61.2 \%$ of Nigerians were living below $\$ 1$ per day; and most of these people are to be found in the north. The report said poverty and inequality in income distribution has been on a steady increase in the country since 2003 , but by 2011 the situation had worsened.

The table below further supports why a section of northern Nigerian youths may subscribe to Boko Haram mobilization.

\begin{tabular}{|c|c|c|c|c|c|c|c|c|}
\hline & \multicolumn{2}{|c|}{ Sector } & \multicolumn{9}{c|}{ Zone } \\
\hline Year & $\begin{array}{c}\text { Urban } \\
\%\end{array}$ & $\begin{array}{c}\text { Rural } \\
\%\end{array}$ & $\begin{array}{c}\text { South south } \\
\%\end{array}$ & $\begin{array}{c}\text { South east } \\
\%\end{array}$ & $\begin{array}{c}\text { South west } \\
\%\end{array}$ & $\begin{array}{c}\text { North central } \\
\%\end{array}$ & $\begin{array}{c}\text { North east } \\
\%\end{array}$ & $\begin{array}{c}\text { North west } \\
\%\end{array}$ \\
\hline 1980 & 17.2 & 28.3 & 13.2 & 12.9 & 13.4 & 32 & 35.6 & 37.7 \\
\hline 1985 & 37.8 & 51.4 & 45.7 & 30.4 & 38.6 & 50.8 & 54.9 & 52.1 \\
\hline 1992 & 37.5 & 46.0 & 40.8 & 41.0 & 43.1 & 46.0 & 54.4 & 36.5 \\
\hline 1996 & 58.2 & 69.3 & 58.2 & 53.5 & 60.9 & 64.7 & 70.1 & 77.2 \\
\hline 2004 & 43.2 & 63.3 & 35.1 & 26.7 & 43.0 & 67.0 & 72.2 & 71.2 \\
\hline
\end{tabular}

Sources: National Bureau of Statistics, NBS (2005)

The situation today (ten years after) would have seriously worsened considering the rapid increase in violence and death rate especially from Boko Haram activities there.

\section{Implication for National Security and Development}

The above scenario, as is obvious, has very serious implications for the state's socio-economic and political development. Let us consider particularly the following specific variables:

Budget: In response to the parlous security situation in the country, particularly in the North, the sum of N921.9 billion was voted for security in the 2012 federal budget even when this means that other sectors considered critical to the survival of the economy such as health, electric power, agriculture, education, science and technology and works, among 
others will suffer. For instance, N400.148 billion voted for the education sector is said to be a far cry from the 26 percent basic minimum recommended by UNESCO. Also, as important as electric power is, the sector got only N161.42 billion, while agriculture was allocated N78.98 billion. Other sectors got allocations far less than what was allocated to defense (see Tell, 14 May, 2012:47). Regrettably, this jumbo security vote, which is the highest sectoral allocation even though the country is not at war, did not yield any substantial dividend as experience that year later showed.

Rapid Death Rate and Loss of Property: The rate at which human lives are lost in the northern part of the country in recent time has become very worrisome. In fact, almost every week both local and foreign media are awash with stories about the activities of Boko Haram. For instance, in Maiduguri, bomb explosion has become a daily occurrence along major roads in the city resulting in an estimated death of 3,000 people together with about 200 churches burnt alongside other public and private infrastructure since 2009 when the crisis began. Ogunwale (2013:1) captures it further:

The sect members have also claimed responsibility for killing of students and burning of schools. In Borno, no fewer than 80 classrooms have been burnt, according to Governor Kashim Shetima.

The economic implication of all these, together with others unofficially reported leaves very much to be desired.

Effect on Investment: This has a dual implication. First, foreign investors are seriously scared away from coming to invest in Nigeria especially now that the country is almost categorized as a terrorist state. Secondly, these incessant attacks suffers the economy. Ben Uzor in Business Day (2012:3) states:

A raft bomb attack on telecommunication installation in northern part of Nigeria is taking its toll on the economy. Over 30 Base Transceiver Stations (a critical network infrastructure required in delivering telecoms service) owned by some major operators such as Airtel, Globalcom, and Etisalat have so far been destroyed. Following this development, critical sectors such as banking, security and manufacturing, which depend on telecoms for efficiency, have been cut off from the global economy.

This will be better appreciated when we do a comparative study of investment in this sector before now. For example, the expansion of telecom facilities in the country increased the inflow of Foreign Direct Investment (FDI) from $\$ 18$ billion in 2009 to $\$ 25$ billion this year. Similarly, small and medium scale business run by non indigenes had been shut down while their proprietors relocate to other parts of the country, thus putting the northern region at a loss of N25 billion daily due to Boko Haram violence (Tell July 23, 2012:20-21).

Other socio-economic implications include: decrease in the standard of education, migration and de-urbanization, psychological trauma, deepening of interreligious intolerance and conflict, and of course weakening of the state.

\subsection{Impact on Politics}

The much clamoured statement by the Nigerian president Goodluck Jonathan, that his cabinet has been infiltrated by the Boko Haram indeed calls for worry. This is confirmed by the way in which the polity has been recently over-heated. The nomination of Retired General Muhammadu Buhari as a negotiator for the Boko Haram, the allegation against Senator Ali Ndume of being one of the brains behind Boko Haram, and the fingering of Ali Modu Sheriff, former governor of Borno state as one of the patrons of the sect, all portend danger for the strength of the state. The weakness of the state is further explained in its decision to draw up a negotiation on whether granting of amnesty will pacify the sect. All these, according to Nossiter (2012:37), have the capacity to decline national cohesion and identity, undermine state legitimacy thus throwing up a considerable loss of confidence on the machinery of government.

\section{Conclusion and Recommendations}

The violent conflict in Nigeria, particularly in the northern part, has become so highly intensified and indeed Hobbesian that the people are now living in "perpetual fear of everyone against everyone else". The situation has even worsened with the lack of motivation, poverty of integrity, in-fighting within the Nigerian politico-security system and most importantly the weakened character of the Nigerian state (Akubor 2011:76). The Boko Haram insurgency group is daily acquiring dastardly innovations in the method of carrying out their activities. Although the Nigerian state has adopted some form of liberal approach to solving the problem, namely the setting up of the Presidential Committee on Dialogue and Peaceful Resolution of Security Challenges in the North, chaired by Alhaji Taminu Turaki (SAN), it has relied heavily on state violence (e.g state of emergency on Yobe, Borno and Adamawa states). This dual approach is not likely to yield good result as it lacks an all-inclusive, institutionalized and concrete economic content.

Sequel to the above, the following recommendations have become necessary in this work.

(i) Boko Haram members should be accommodated in the state economic planning process through an allinclusive development-oriented agenda or interventionist platform rather than adopting an elitist approach of 
dealing only with stakeholders.

(ii) The problem of poverty needs to be tackled at its roots - possibly from the village level.

(iii) The Economic and Financial Crimes Commission (EFCC) should be restructured and decentralized to critically monitor the appropriation of local government councils' allocations to ensure that resources are deployed to projects with potentials for human capital development at the rural level.

(iv) Government at all levels should adopt an institutionalized framework of setting up of a Religious Tolerance Commission while the National Orientation Agency makes it a duty to embark on serious religious tolerance campaigns through out the country as part their responsibilities.

(v) We equally advocate the entrenchment of the rule of law and good governance in the country as a means of delivering justice to oppressed members of society who may have formed the bulk of the Boko Haram sect.

Again, civil society groups, community based organizations (CBO), faith based organizations (FBOs) also have to seriously initiate social engagement, enlightenment and advocacy programmes to change the world-view of the Boko Haram members.

The intra party conflicts especially within the ruling People's Democratic Party (PDP) need to be resolved to avoid using Boko Haram members as weapons against perceived political opponents.

\section{References}

Adefuye, A. I. (2012) "Boko Haram: America is determined to help Nigeria", in Tell Magazine, Lagos, September 3.

Adeyemo, W. (2011) "Turning the Heat on Boko Haram" in Tell magazine, Lagos, December 5.

Agbo, A. (2011) "Boko Haram: Jonathan's Big Dilemma" Tell Magazine, Lagos, August 1.

Agbo, A. (2011) "War Against Peace" in Tell Magazine Lagos, October 3.

Ake, C. (1981) A political economy of Africa, London, Longman.

Ake, C. (1985), (ed) A political economy of Nigeria: New York, Longman.

Akubor, E. (2011) "Civil Unrest in Northern Nigeria: Beyond the literal "Boko Haram" in The Constitution: A Journal of Constitutional Development 11(4) December.

Alabi, D. O. (2007), "Religious Conflicts in Northern Nigeria: A critical Analysis" in Peterside, S. and Ukoha, U. (eds) The Travails and Challenges of Democracy in Nigeria, 1990-2003 and Beyond. Port Harcourt, CASS Publication.

Ben, U. (2012), In Business Day 24, Sept.

Dasuki, I. (2012) "Northern Leaders can't Tackle Boko Haram" in Tell Magazine, Lagos, March 12.

Ekekwe, E. (2009) An Introduction to Political Economy. Port Harcourt, Chuzzy Services Nigeria.

Federal Republic of Nigeria, Report to the Constitution Drafting Committee Containing the draft constitution. Vol. P. X. cited in Nonie 1988.

Gaya, B. et al. (eds) (2005) Introduction to Peace and Conflict in West Africa, Spectrum Books, Ibadan.

Goulbourne, H. (ed) (1979) Politics and State in the Third World: London, The Macmillan Books Ltd.

Ikponmwen, D. I. (2012) "Why Federal Government can't tackle Boko Haram Sponsors" in Tell Magazine, Lagos, May 21.

Isenyo, G. (2013) "Federal government should disown Boko Haram amnesty panel". In The Punch, July 15

Jega, A. (2002), "Tackling Ethno-Religious Conflict in Nigeria" in The Nigerian Social Scientist (Newsletter of the Social Science Academy of Nigeria), 5(2).

Lenin, V.I. (1977) On Dialectical Materialism, Moscow: Progress Publishers.

Lenin, V. I. (1976), The State and Revolution, Peking: Foreign Languages Press.

Lenin, V. I. (1978), Marx, Engels, and Marxism, Peking, Foreign Language Press

Marx, F. and Engels, F. (1977), Manifesto of the Communist party, Moscow: Progress Publishers.

Mordi, R. (2011) "Boko Haram and Scientific Collapse" in Tell magazine, Lagos, May 21

Mudashiru, (2011) "Understanding the Dimensions of the New Face of Terror: A Political Economic of African Terrorist Groups" in The Constitution. A Journal of Constitutional Development, 11(4) 4 December.

Nossiter, A. (2012) "Boko Haram's Deadly Rage has Local Roots". in Tell Magazine, Lagos, October 8.

Nwangwu, C. U. S African Online. An Internet Publication 10/12/2005.

Ogunwale, G. (2013) "Boko Haram: Army takes over operations" in The Nation August, 19

Okei-Odumakin, J. (2011) in Tell Magazine, Lagos, September 26.

Okodudu, S. (2010) Issues in the socio-economic and political development of Nigeria. Pan African Social Science Review.

Onuorah, M. (2013) "War against terrorists begins". The Guardian, May 16.

Sani, S. (2011) "Boko Haram: History, ideas and Revolt". In The Constitution. A Journal of Constitutional Development, 11(4) December.

Stewart, F. (2007) "How does conflict Undermine Human Development?" United Nations Human Development Report Office, Oxford Source: www.hdr.undp.org/network/messageview

Suleiman, T. (2012a) "Boko Haram Defies State of Emergency" in Tell Magazine, Lagos, January 23.

Suleiman, T. (2012b) "Boko Haram Siege: Nigeria in BombDage" in Tell Magazine, Lagos, February 6.

Suleiman, T. (2012c) "The cost of Boko Haram" in Tell Magazine, Lagos, May 14.

Suleiman, T. (2012d) "The North is Dying" in Tell Magazine, Lagos, July 23.

Suleiman, T. (2012e) "City under siege: they have killed Maiduguri for us" in Tell Magazine, Lagos, September 17.

Tell Magazine (2011) "Living in the Shadows of Boko Haram", Lagos, November 21.

Tell Magazine (2011) "Rumblings over security: can Goodluck Sustain Jonathan till 2015 "Lagos, August 20.

Tell Magazine (2011) "Why Boko Haram is Winning" in, Lagos, July 4.

The Nation (2013) "Boko Haram disown cease fire pact with Government" Lagos, July 14.

Wole, A. (2011) "How to tackle Boko Haram" in Tell, Magazine, September 26.

www.the.guardian.com/world/BokoHaram.15/05/2013 